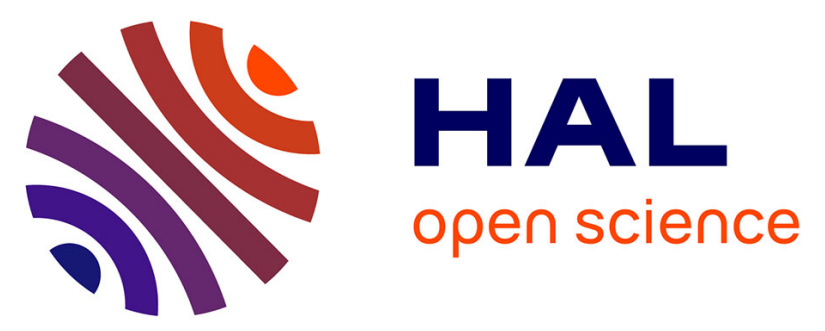

\title{
Extremely reducing conditions reached during basaltic intrusion in organic matter-bearing sediments
}

\author{
Giada Iacono-Marziano, Fabrice Gaillard, Bruno Scaillet, Alexander G. \\ Polozov, Virginie Marecal, Michel Pirre, Nicholas Arndt
}

\section{- To cite this version:}

Giada Iacono-Marziano, Fabrice Gaillard, Bruno Scaillet, Alexander G. Polozov, Virginie Marecal, et al.. Extremely reducing conditions reached during basaltic intrusion in organic matter-bearing sediments. Earth and Planetary Science Letters, 2012, 357-358, pp.319-326. 10.1016/j.epsl.2012.09.052 . insu-00745334

\section{HAL Id: insu-00745334 \\ https://hal-insu.archives-ouvertes.fr/insu-00745334}

Submitted on 25 Oct 2012

HAL is a multi-disciplinary open access archive for the deposit and dissemination of scientific research documents, whether they are published or not. The documents may come from teaching and research institutions in France or abroad, or from public or private research centers.
L'archive ouverte pluridisciplinaire HAL, est destinée au dépôt et à la diffusion de documents scientifiques de niveau recherche, publiés ou non, émanant des établissements d'enseignement et de recherche français ou étrangers, des laboratoires publics ou privés. 


\title{
Extremely reducing conditions reached during basaltic intrusion in organic matter-bearing sediments
}

\author{
Giada IACONO-MARZIANO ${ }^{1 *}$, Fabrice GAILLARD ${ }^{1}$, Bruno SCAILLET ${ }^{1}$, Alexander G. \\ POLOZOV $^{2}$, Virginie MARECAL ${ }^{3}$, Michel PIRRE ${ }^{4}$ \\ and Nicholas T. ARNDT ${ }^{5}$
}

\author{
${ }^{1}$ CNRS/INSU, ISTO, UMR 7327, Orléans, France \\ ${ }^{2}$ Institute of Geology of Ore Deposits, Petrography, Mineralogy and Geochemistry, Russian \\ Academy of Sciences, 119017 Moscow, Russia \\ ${ }^{3}$ CNRM-GAME, Météo-France and CNRS URA 1357, Toulouse, France \\ ${ }^{4}$ LPC2E, UMR 6115 CNRS-Université d'Orléans, Orléans, France \\ ${ }^{5}$ ISTerre, Université de Grenoble, Grenoble, France \\ *Corresponding author: Giada.Iacono@cnrs-orleans.fr, 1A rue de la Férollerie 45071 Orléans \\ cedex 2, France. Tel: 0033238257868. Fax: 0033238636488.
}

\begin{abstract}
Redox conditions in magma are widely interpreted as internally buffered and closely related to that of their mantle source regions. We use thermodynamic calculations to show that hightemperature interaction between magma and organic matter can lead to a dramatic reduction of the magma redox state, and significant departure from that of the original source. Field studies provide direct evidence of the process that we describe, with reported occurrences of graphite and native iron in igneous mafic rocks, implying very reducing conditions that are almost unknown in average terrestrial magmas. We calculate that the addition of $0.6 \mathrm{wt} \%$
\end{abstract}


organic matter (in the form of $\mathrm{CH}$ or $\mathrm{CH}_{2}$ ) to a standard basalt triggers graphite and native iron crystallisation at depths of few hundred meters.

Interaction with organic matter also profoundly affects the abundance and the redox state of the gases in equilibrium with the magma, which are CO-dominated with $\mathrm{H}_{2}$ as the second most abundant species on a molar basis, $\mathrm{H}_{2} \mathrm{O}$ and $\mathrm{CO}_{2}$ being minor constituents. The assimilation of only $0.1 \mathrm{wt} \%$ organic matter by a basalt causes a decrease in its oxygen fugacity of 2-orders of magnitude. The assimilation of $0.6 \mathrm{wt} \%$ organic matter at depths $<500$ $\mathrm{m}$ implies minimum $\mathrm{CO}$ content in the magma of $1 \mathrm{wt} \%$, other gas components being less than $0.1 \mathrm{wt} \%$. In the light of our calculations, we suggest that the production of native ironbearing lava flows and associated intrusions was most likely accompanied by degassing of CO-rich gases, whose fluxes depended on the magma production rates.

Key words: magma-organic matter interaction, graphite native iron saturation, gas emissions, carbon monoxide, Siberian Traps, Disko Island.

\section{Introduction}

Volcanic gases may have critically influenced the evolution of planetary atmospheres and biogeochemical cycles (Holland, 2002; Kump and Barley, 2007; Gaillard et al., 2011). The classic view is that the nature and the abundance of gas emanations reflect redox state and volatile abundances of the magma source region in the mantle (Jambon, 1994; Carmichael, 1991). Volatiles are released to the atmosphere during volcanic degassing and re-introduced into the mantle by subduction (e.g. Hilton et al., 2002; Wallace, 2005). Mantle redox state is considered to have undergone little evolution over much of Earth history (Canil, 2002; Li and Lee, 2005; Trail et al., 2011), resulting in $\mathrm{H}_{2} \mathrm{O}-\mathrm{CO}_{2}-\left(\mathrm{SO}_{2}\right)$ dominated volcanic gases for most magmas, regardless of their tectonic setting and age (Li and Lee, 2005; Gaillard et al., 2011; Trail et al., 2011). This picture is corroborated by geochemical surveys of the composition of 
volcanic gases emitted by active volcanoes (e.g. Symonds et al., 1994; Aiuppa et al., 2007, 2012; Edmonds and Gerlach, 2007; Metrich et al., 2011), showing that volcanic species are mainly composed of $\mathrm{H}_{2} \mathrm{O}, \mathrm{CO}_{2}$ and $\mathrm{SO}_{2}$. Recent works show, however, that magma-host rock interaction contributes additional gases that can enhance or even overwhelm the mantlederived contribution (Svensen et al. 2004, 2007, 2009; Iacono-Marziano et al., 2007, 2009; Ganino and Arndt, 2009; Troll et al., 2012), and locally impacts the magma redox state (Ganino et al., 2008). During continental flood magmatism, contact metamorphism of country rocks is proposed to have controlled the nature of gas emissions and their environmental consequences (Svensen et al. 2004, 2007, 2009; Ganino and Arndt, 2009). The high biological impact ascribed to the emplacement of the Siberian Traps and the Emeishan igneous province, for instance, has been attributed to the occurrence of carbonates, evaporites and organic matter-rich rocks in the sedimentary sequences traversed by ascending magmas (Svensen et al. 2004, 2009; Ganino and Arndt, 2009). Previous studies focused on low temperature $\left(<650^{\circ} \mathrm{C}\right)$ contact metamorphism, which generates carbon and sulphur gases $\left(\mathrm{CO}_{2}, \mathrm{CH}_{4}, \mathrm{SO}_{2}\right)$ and halocarbons (Svensen et al. 2004, 2007, 2009; Ganino and Arndt, 2009; Retallack and Jahren, 2008). The high temperature contribution of magmatic assimilation has been generally neglected, being difficult to quantify (Ganino and Arndt, 2009). Here we study the high temperature $\left(1200^{\circ} \mathrm{C}\right)$ assimilation of carbonaceous rocks into basaltic magmas, by simulating the incorporation of organic matter in the form of $\mathrm{CH}$ or $\mathrm{CH}_{2}$, and investigating its effect on the redox state of the magma, its mineralogical assemblage and its volatile content. Crystalmelt-gas equilibria are first explored via thermodynamic calculations, taking into account both magmatic and sedimentary contributions to gas production. The conditions of basaltorganic matter interaction in relevant geological settings will be then presented.

Numerous studies have investigated the composition and the thermodynamics of volcanic gases, paying particular attention to the redox processes governing their composition (e.g. 
Giggenbach 1987, 1997; Gerlach, 1993; Moretti et al, 2004). Giggenbach (1987) dealt with C-O-N-H-S gases, taking into account the role of the rock matrix in buffering their redox conditions. Gerlach (1993) investigated C-O-H-S-Cl-F species and modelled their exchanges with the melt in terms of transfer of oxygen from the gas to the lava. Moreover, Giggenbach (1997) explored the role of organic sedimentary material in the production of natural carbon gasses. Compared to these studies, the main originality of our work is that we combine: (i) high temperature magmatic conditions, (ii) gas-melt equilibria, i.e. not only oxygen exchange between gas and melt is taken into account, but also the solubility of some gas species in the melt, (iii) open system conditions, i.e. both magmatic and non-magmatic volatiles are considered, (iiii) saturation of graphite and native iron in the melt, as we deal with reduced condition.

\section{Methods: thermodynamic calculations}

We modelled the composition of volcanic gases resulting from interaction with organic matter and magma degassing. To reach this aim we used gas-melt thermodynamic calculations that take into account $\mathrm{S}-\mathrm{H}-\mathrm{O}-\mathrm{C}$ gaseous species at temperatures and pressures in equilibrium with basaltic liquids (Gaillard and Scaillet, 2009; Gaillard et al., 2011). We considered that the melt, prior to interaction with organic compounds, is basaltic in composition with $8 \mathrm{wt} \% \mathrm{FeO}$. At the initial conditions $\left(\mathrm{P}=200 \mathrm{MPa}, \mathrm{T}=1200^{\circ} \mathrm{C}\right)$ the basaltic melt is saturated in $\mathrm{CO}_{2}, \mathrm{H}_{2} \mathrm{O}$ and S: $0.08,0.50$ and $0.10 \mathrm{wt} \%$ respectively (Mavrogenes and O'Neill, 1999; IaconoMarziano et al., in press). We investigated the roles of the initial oxidation state and gas content of the magma prior to interaction and tested the effect of coal $(\mathrm{CH})$ or hydrocarbon $\left(\mathrm{CH}_{2}\right)$ incorporation. The initial oxygen fugacity $\left(\mathrm{fO}_{2}\right)$ of the magma varied between the Fayalite-Magnetite-Quartz (FMQ) and the Nickel-Nickel Oxide (NNO) buffers, as generally observed in basaltic magmas ( $\mathrm{Li}$ and Lee, 2005), yielding $\mathrm{Fe}_{2} \mathrm{O}_{3} / \mathrm{FeO}$ mole ratios between 
0.07 and 0.11 . The initial (i.e. at $200 \mathrm{MPa}$ ) gas content of the magma was between 0.3 and 0.7 $\%$, yielding total volatile contents (dissolved in the melt + bubbles) of $0.50 \mathrm{wt} \% \mathrm{H}_{2} \mathrm{O}, 0.10$ wt $\% \mathrm{~S}$ and 0.24-0.64 wt\% $\mathrm{CO}_{2}$, which are typical of undegassed basalts (Dixon et al., 2008). We tested initial dissolved water content between 0.2 and $1 \mathrm{wt} \%$ and found it to have a negligible influence on our calculations. Starting conditions are listed in Table 1. Calculations show also that varying the total $\mathrm{FeO}$ content of the basalt between 8 and 13 wt $\%$ changes by less than $5 \%$ the concentration of the species with mole fractions higher than 0.1 .

The gas composition was calculated following Gaillard and Scaillet (2009) and Gaillard et al. (2011). This methodological approach is long known as the "Equilibrium constants and mass balance method" (Holloway, 1987) to calculate equilibria in the C-O-H system, briefly recalled below. The mole fractions of the different gas species were calculated from the thermodynamic constants of the following reactions at P and T (after Shi and Saxena, 1992).

$$
\begin{array}{lll}
\mathrm{C}^{\text {[graphite] }}+\mathrm{O}_{2} & = & \mathrm{CO}_{2}{ }^{\text {[fluid] }} \\
\mathrm{CO}^{\text {[fluid] }}+1 / 2 \mathrm{O}_{2} & = & \mathrm{CO}_{2}{ }^{\text {[fluid] }} \\
\mathrm{H}_{2}{ }^{\text {ffluid] }}+1 / 2 \mathrm{O}_{2} & = & \mathrm{H}_{2} \mathrm{O}^{\text {[fluid] }} \\
\mathrm{CH}_{4}{ }^{\text {[fluid] }}+\mathrm{O}_{2} & = & \mathrm{CO}_{2}{ }^{\text {[fluid] }}+2 \mathrm{H}_{2} \mathrm{O}^{\text {[fluid] }} \\
1 / 2 \mathrm{~S}_{2}{ }^{\text {ffluid] }}+\mathrm{O}_{2} & = & \mathrm{SO}_{2}{ }^{\text {ffluid] }} \\
\mathrm{H}_{2} \mathrm{~S}^{\text {[fluid] }}+1 / 2 \mathrm{O}_{2} & = & 1 / 2 \mathrm{~S}_{2}{ }^{\text {[fluid] }}+\mathrm{H}_{2} \mathrm{O}^{\text {[fluid] }}
\end{array}
$$

Melt-gas equilibria were also considered:

$$
\begin{array}{lll}
\mathrm{H}_{2} \mathrm{O}^{\text {[fluid }]}+\mathrm{O}^{2-[\text { melt }]} & = & 2 \mathrm{OH}^{- \text {[melt }]} \\
\mathrm{CO}_{2}{ }^{\text {[fluid }]}+\mathrm{O}^{2-[\text { melt }]} & = & \mathrm{CO}_{3}{ }^{2 \text { - [melt }]} \\
\mathrm{S}_{2}{ }^{\text {[fluid }]}+2 \mathrm{O}^{2-[\text { melt }]} & = & \mathrm{O}_{2}+2 \mathrm{~S}^{2-[\text { melt }]} \\
2 \mathrm{FeO}^{\text {[melt }]}+1 / 2 \mathrm{O}^{2-\text { [gas }]} & = & \mathrm{Fe}_{2} \mathrm{O}_{3}{ }^{\text {[melt }]}
\end{array}
$$

Equilibria (1) to (6) and (10) were simultaneously solved at every given pressure and temperature, under the requirement that the amounts of $\mathrm{H}, \mathrm{S}, \mathrm{O}$ and $\mathrm{C}$ remain constant in the 
system (gas + melt + graphite). Seven redox couples were considered for each calculation, involving sulphur (with 3 different redox states), carbon (with 4 different redox states) and hydrogen (with 2 different redox states), together with iron (2 redox states). Each equilibrium constant for equilibria from (1) to (6) is compiled in Symonds and Reed (1993), while solubility laws for $\mathrm{H}_{2} \mathrm{O}, \mathrm{CO}_{2}$ and $\mathrm{S}$ (equilibria 7-9) were taken from Iacono-Marziano et al. (in press) and Mavrogenes and O'Neill (1999). The ferric-ferrous equilibrium (10) was computed after Kress and Carmichael (1991). The concentrations of reduced C species (e.g. $\left.\mathrm{CO}, \mathrm{CH}_{4}\right)$ in the basaltic melt was neglected in our calculations, as they are known to have very low solubility in a basaltic melt at 200-300 MPa (Pan et al., 1992; Morizet et al., 2010). In conclusion, our approach combines existing experimental studies performed on specific volatiles into a multi-component model, under the assumption of gas-melt equilibrium.

Organic matter was incrementally added up to $0.8 \mathrm{wt} \%$. Two types of organic compounds were taken into account, $\mathrm{CH}$ and $\mathrm{CH}_{2}$, which are representative of mature organic matter that is most likely to interact with basaltic magmas (e.g. coal or petroleum). To simplify our calculations, we ignore the possible presence of oxygen in the organic matter, as the oxygen content generally decreases with the maturity of the organic matter (Hetenyi, 1998).

Degassing is simulated by decreasing pressure, keeping the masses of the different components $(\mathrm{H}, \mathrm{S}, \mathrm{C}, \mathrm{O})$ constant. Gas compositions are calculated at variable final pressures and shown below for 10 and $0.1 \mathrm{MPa}$. Figure 1 in the Supplementary Material schematically summarizes the strategy of the numerical calculations.

\section{$\underline{\text { 3. Results }}$}

\subsection{Fluid phase composition}

Assimilation of organic matter has dramatic effects both on the amount and the redox state of the gases in equilibrium with the basalt (Fig.1). When no organic matter is assimilated the 
fluid phase consists mainly of $\mathrm{H}_{2} \mathrm{O}$ and $\mathrm{CO}_{2}$ (respectively $0.52-0.66$ and $0.15-0.33$ on a molar basis, with $0.05-0.14 \mathrm{SO}_{2}$, and $\mathrm{H}_{2}, \mathrm{CO}, \mathrm{H}_{2} \mathrm{~S}$ and $\left.\mathrm{S}_{2}<0.05\right)$ as typically observed in volcanic gas emissions from basalts worldwide (Symonds et al., 1994; Edmonds and Gerlach, 2007). Figure 1 (see also Figure 2 in the Supplementary Material) shows the influence of the initial conditions (initial gas content of the magma and initial $\mathrm{fO}_{2}$ ) on gas phase compositions at 0.1 $\mathrm{MPa}$ resulting from the assimilation of $\mathrm{CH}$ or $\mathrm{CH}_{2}$. For $\mathrm{CH}$ addition, we show how gas composition varies for initial $\mathrm{fO}_{2}$ of $\mathrm{NNO}$ or $\mathrm{FMQ}$, and for an initial gas proportion of 0.3 or $0.7 \%$ of the magma. More oxidizing conditions (initial $\mathrm{fO}_{2}$ of $\mathrm{NNO}$ ) slightly favours the survival of oxidized species (e.g. $\left.\mathrm{H}_{2} \mathrm{O}, \mathrm{CO}_{2}\right)$ and $\mathrm{S}$ species in general $\left(\mathrm{H}_{2} \mathrm{~S}, \mathrm{~S}_{2}, \mathrm{SO}_{2}\right)$ for a given amount of organic matter added to the system. Higher initial gas contents ( $0.7 \mathrm{wt} \%)$ also slightly promote oxidized species relative to reduced ones. The most extreme cases are therefore represented by: (i) $\mathrm{fO}_{2}=\mathrm{NNO}$ and gas proportion $=0.7 \%$ (Fig.1a), and (ii) $\mathrm{fO}_{2}=$ FMQ and gas proportion $=0.3 \%$ (Fig. $1 \mathrm{~b}$ ). $\mathrm{CH}_{2}$ addition slightly enhances the production of $\mathrm{H}_{2}$ respect to that of $\mathrm{CO}$. Similarly to $\mathrm{CH}$ addition, the two most extreme cases are shown in Fig.1c and d. In all cases, with the assimilation of only $0.25-0.35 \mathrm{wt} \% \mathrm{CH}$ or $\mathrm{CH}_{2}$, the gas composition changes from $\mathrm{CO}_{2}-\mathrm{H}_{2} \mathrm{O}$ dominated to strongly reduced and $\mathrm{CO}-\mathrm{H}_{2}$ dominated. In general, the effects of the initial $\mathrm{fO}_{2}$ and gas fraction are minor, as are differences arising from whether $\mathrm{CH}$ or $\mathrm{CH}_{2}$ is added: in all cases the degassing trends are very similar and the amount of the dominant species (i.e. those with mole fractions $>0.1$ ) changes by less than $30 \%$, for a given amount of organic matter assimilated (Fig.SM2).

\subsection{Graphite and native iron saturation}

An important consequence of the addition of organic matter is the crystallization of graphite from the magma (equilibrium 1). Graphite saturation depends only slightly on factors such as the type of organic matter assimilated $\left(\mathrm{CH}\right.$ or $\left.\mathrm{CH}_{2}\right)$, the initial redox conditions, and the initial 
gas content of the magma but strongly on pressure and therefore on depth (Fig. 2). At pressures higher than $60 \mathrm{MPa}$, graphite crystallizes from the magma when low amounts of organic matter are assimilated (0.1-0.3 wt\%). Coal and oil ingestion at $1200^{\circ} \mathrm{C}$ and graphite crystallization can be simplified as:

(x) $\mathrm{CH}+(\mathrm{y}) \mathrm{O}^{\mathrm{magma}} \rightarrow$ (y) $\mathrm{CO}+(1 / 2 \mathrm{x}) \mathrm{H}_{2}+(\mathrm{x}-\mathrm{y}) \mathrm{C}$

(x) $\mathrm{CH}_{2}+\left(\right.$ y) $\mathrm{O}^{\text {magma }} \rightarrow\left(\right.$ y) $\mathrm{CO}+(\mathrm{x}) \mathrm{H}_{2}+(\mathrm{x}-\mathrm{y}) \mathrm{C}$

where $\mathrm{x}$ and $\mathrm{y}$ are stochiometric coefficients that are essentially affected by pressure. For a given amount of organic matter assimilated (x), high pressure favours graphite crystallization (i.e. low y), while low pressure enhances $\mathrm{CO}$ and $\mathrm{H}_{2}$ production, by subtracting oxygen to the magma (i.e. high y). At shallow depths (i.e. low pressure), increasing $\mathrm{CH}$ or $\mathrm{CH}_{2}$ addition therefore causes a dramatic decrease in magma $\mathrm{fO}_{2}$, whereas at deeper conditions the decrease in $\mathrm{fO}_{2}$ is less pronounced. Reactions (11) and (12) conveniently summarize the overall process of assimilation of organic matter by a basaltic melt, however our calculations also take into account other C-H-O and $\mathrm{S}$ species (i.e. $\mathrm{CO}_{2}, \mathrm{H}_{2} \mathrm{O}, \mathrm{CH}_{4}, \mathrm{~S}_{2}, \mathrm{SO}_{2}, \mathrm{H}_{2} \mathrm{~S}$; see reactions 1 to 6), which have concentrations lower than $1 \mathrm{wt} \%$, and are therefore neglected here for simplifying.

Figure 3 shows the evolution of the redox state of a magma with an initial gas content of 0.3 wt $\%$ at $200 \mathrm{MPa}$ as a function of the assimilated organic matter. The $\mathrm{fO}_{2}$ of the magma rapidly decreases with the addition of organic matter from the FMQ buffer (initially imposed conditions). For only $0.1 \mathrm{wt} \% \mathrm{CH}$ assimilated, $\mathrm{fO}_{2}$ decreases by more than 2 log-units. For more than $0.5 \mathrm{wt} \% \mathrm{CH}$ assimilated, $\mathrm{fO}_{2}$ decreases by $\sim 6 \mathrm{log}$ units (FMQ-6). When the $\mathrm{fO}_{2}$ of the magma reaches FMQ-6, native iron crystallizes (Gaillard and Scaillet, 2009) and buffers magma redox state, until all $\mathrm{FeO}$ is exhausted. The amount of organic matter needed to reach graphite and native iron saturation due to the variable initial conditions (i.e. type of organic matter assimilated, initial gas fraction and initial $\mathrm{fO}_{2}$ of the magma), varies by less than $30 \%$ 
at a given pressure (Fig. 2). At graphite saturation, native iron crystallization occurs with decreasing pressure by graphite volatilization, as expressed by the reaction:

$\mathrm{C}^{\text {graphite }}+\mathrm{FeO}^{\text {magma }} \rightarrow \mathrm{CO}^{\text {gas }}+\mathrm{Fe}^{\text {native }}$

Reaction (13) implies that native iron formation consumes graphite and produces $\mathrm{CO}$, in addition to that supplied by reactions (11) and (12).

We calculate that the critical pressure for native iron saturation to occur is $10 \mathrm{MPa}$. At higher pressures, the redox state of the magma is not reduced enough for native iron to be stable. This critical pressure mainly depends on magma temperature and to a lesser extent on its total iron content. A hotter and Fe richer magma would crystallize native iron at slightly higher depths (e.g. a magma with $13 \mathrm{wt} \%$ total $\mathrm{FeO}$ at $1200^{\circ} \mathrm{C}$ is saturated in native iron at $12 \mathrm{MPa}$ ). Reactions (11-13) can help illustrating what happens to a basaltic magmas ascending through sedimentary sequences containing organic matter-rich layers. When a magma is contaminated deep in a basin with oil or shale, graphite crystallizes for very low amounts of organic matter assimilated (Fig.2). This graphite is then consumed during ascent to degas carbon monoxide, and to produce, at depths of few hundred meters (varying as a function of the density of the sedimentary host rocks), native iron if significant amounts (more than $0.5 \mathrm{wt} \%$ ) of organic matter are assimilated (Fig.2). If the ascending magma also flows through coal-bearing sediments at shallow depths, coal assimilation is even more likely to furnish the amount of organic matter necessary to reach iron saturation. When the magma becomes saturated in native iron, further addition of organic matter does not increase CO degassing, unless pressure is decreased.

A probable side effect of native iron separation that is not taken into account by our model is sulphide precipitation. Native iron separation decreases the total iron content of the melt and therefore also its $\mathrm{FeO}$ content, consequently decreasing the maximum amount of sulphur that it can dissolve (Gaillard and Scaillet, 2009): sulphides are therefore likely to precipitate in 
response to native iron precipitation. However, this process would not produce large amounts of sulphides, given the relatively low $\mathrm{S}$ content of the magma, and would probably happen after the precipitation of relatively large amounts of native iron.

\subsection{Effect of temperature on gas composition}

The effect of temperature on the composition of the gas phase was calculated between 1200 and $300^{\circ} \mathrm{C}$. The gas phase produced at $1200^{\circ} \mathrm{C}$ at graphite and iron saturation $(0.6 \mathrm{wt} \% \mathrm{CH}$ added) was then re-equilibrated at lower temperatures: Figure 4 shows its composition at two different final pressures (0.1 and $10 \mathrm{MPa}$, Fig. $4 \mathrm{a}$ and $\mathrm{b}$, respectively). While at magmatic temperatures $\left(>1000{ }^{\circ} \mathrm{C}\right)$ the gas phase is $\mathrm{CO}-\mathrm{H}_{2}$-dominated, it is mainly constituted of $\mathrm{H}_{2} \mathrm{O}$, $\mathrm{CH}_{4}$ and $\mathrm{CO}_{2}$ when the temperature decreases below $500^{\circ} \mathrm{C}$. Such low temperature gases are close in composition to those resulting from thermal metamorphism of country rocks (Svensen et al., 2009).

\section{Field evidence of magma-organic matter interactions}

The presence of igneous graphite in mafic rocks has been interpreted as an evidence of magma-organic matter interaction in different geological contexts, e.g. at the Karoo Basin, South Africa (Henning et al., 1997), or at Borrowdale in Cumbria, United Kingdom (Ortega et al., 2010). However, the occurrence of native iron in basaltic extrusive or intrusive rocks is probably the clearest evidence of extremely reducing conditions reached during magmatic assimilation of carbonaceous rocks (crystallization of native iron implying oxygen fugacities lower than FMQ-6); three unambiguous cases are presented below.

\subsection{Disko Island, Greenland}


The first occurrences of native iron in basaltic magmas were found at the island of Disko in central West Greenland (Nordenskjöld, 1872). Since then, disseminated native iron has been described in several basalts at Disko, associated with wustite, carbides and sulphides (Steenstrup, 1884; Pedersen, 1979a,b 1985; Ulff-Møller, 1985). Numerous graphite rich xenoliths have been also found throughout the iron bearing basalts and interpreted as thermally metamorphosed fragments from the underlying bituminous shales on the basis of their mineral assemblages and sedimentary structures (Melson and Switzer, 1966 ; Pedersen, 1978, 1979b).

Disko lavas belong to the Paleocene volcanic succession related to the North Atlantic mantle plume (Pedersen and Larsen, 2006). They were emplaced in the Nuussuaq Basin (part of the West Greenland Basin), whose Cretaceous and Tertiary sedimentary sequences comprise abundant carbonaceous sediments including coal seams up to $2 \mathrm{~m}$ thick (Medenbach and ElGoresy, 1982), which severely contaminated picritic magmas (see Pedersen and Larsen, 2006 for a review). The crustally contaminated rocks occur as dykes, necks, lava flows and tuffs and contain variable amounts of graphite and native iron. At the classic locality of Asuk, a $~ 100 \mathrm{~m}$ thick sequence of sediment-contaminated lavas, mostly iron-bearing, occurs in which baked, party glassy, shale xenoliths are frequent, some still preserving sedimentary bedding (Pedersen, 1979a). Pedersen and Larsen (2006) proposed that the abundance of graphite and native iron in the Disko and Nuussuaq rocks depends on the pressure at which they equilibrated: using thermodynamic estimations of the equilibrium between graphite and a C-H-O gas phase at high temperature and pressure (French and Eugster, 1965; French, 1966), they predicted an equilibration pressure of 0.1 MPa for Disko lavas and 50-100 MPa for the native iron free graphite andesite tuffs from Nuussuaq. This is in a very good agreement with what our calculations predict.

\subsection{Bühl, Germany}


Native iron-bearing xenoliths have also been observed in Miocene alkali basalts at Bühl near Kassel, in West Germany (Medenbach and ElGoresy, 1982). The xenoliths have been found in a basalt pipe that intruded Tertiary coal seams and have been interpreted as the products of a reduction under near surface conditions $(<10 \mathrm{MPa})$ of manganese-bearing iron minerals contained in Tertiary sediments and coal seams cut by the erupting basalts (Medenbach and ElGoresy, 1982). Carbon from coal has been considered as the reducing agent (Medenbach and ElGoresy, 1982).

\subsection{Siberian Platform, Russia}

The highest concentrations of native iron in magmatic rocks have been observed in the North and North-west of the Siberian Platform, in several trap intrusions hosted by the Middle Carboniferous-Permian coal-bearing terrigenous deposits (Ryabov and Lapkovsky, 2010). The occurrence and composition of native iron in the different intrusions (Maimecha, Khininda, Khungtukun intrusions, Dzhaltul igneous complex and Ozernaya Mountain intrusion) are very similar. Two types of native iron have been recognized: fine disseminations $(0.2-0.5 \mathrm{~mm}$ ) in dyke-like bodies and nodules (up to $200 \mathrm{~kg}$ in weight) concentrated in the upper zone of the intrusions (or of the first intrusive phase in the Dzhaltul complex). Dyke-like bodies are 0.3-3.9 m-thick and contain fragments of sedimentary rocks.

The 2-40 m thick nodule-bearing horizons are located within a 40-110 m-thick olivine gabbro zone where they are associated with graphite, carbides and finely dispersed carbonaceous matter. The quantity and size of nodule increase upwards in the ore-bearing horizons. The current depths of native iron mineralizations are between 40 and $600 \mathrm{~m}$. Subsidence of several hundred meters throughout the Mesozoic and Cenozoic has been, however, estimated for the West Siberian Basin (Saunders et al., 2005). 
Several lines of evidence suggest that the temperature of ore formation was $750-1200{ }^{\circ} \mathrm{C}$ and that at least some of the native iron formed before the crystallization of silicates, e.g. native iron inclusions occur in plagioclase, olivine and pyroxene (Ryabov and Lapkovsky, 2010). Although sulphides are commonly associated with the native iron, the total sulphur content of the mineralization is $<0.2 \mathrm{wt} \%$. Carbon isotopic compositions of graphite and carbides are similar to that of the organic matter (Ryabov and Lapkovsky, 2010). More generally, the occurrence of varying amounts of finely dispersed carbonaceous matter and its carbon isotopic composition suggest that nearly all ore-bearing intrusions in the northwest of the Siberian Platform have been contaminated by carbonaceous matter to different extents (Ryabov et al., 2006; Ryabov and Lapkovsky, 2010). Carbonaceous matter occurs in the form of amygdales in dolerite of explosive breccias, and also as small rounded inclusions in plagioclase (Ryabov et al., 2006; Ryabov and Lapkovsky, 2010). Abundant bitumen-filled amygdules (schungite) in volcanic units of the Noril'sk region and massive reduction of

sulphate to sulphide during the formation of the major Ni sulphide deposits of the NorilskTalnakh region (Arndt et al., 2005) provide additional evidence of interaction with hydrocarbons.

\section{$\underline{\text { 5. Gas emissions produced by assimilation of organic matter }}$}

Native iron-bearing intrusions and lava flows described in the previous section are hosted in, or associated with, coaliferous strata and bituminous shales, suggesting that graphite and native iron saturation was triggered by assimilation of organic matter (mainly coal). Our calculations restrict native iron crystallization to pressures lower than $10 \mathrm{MPa}$ (Fig. 2), i.e. 350-500 $\mathrm{m}$, depending on the density of the overlying sedimentary rocks, however the ingestion of organic matter could have happened also at deeper levels (e.g. where petroleum accumulations occur). The occurrence of native iron constrains the minimum amount of 
organic matter assimilated (either $\mathrm{CH}$ or $\mathrm{CH}_{2}$ ) to be 0.5 wt \% (Fig.2). Moreover, the coexistence of graphite and native iron also constrains the composition of the fluid phase. At 0.1 MPa, the fluid phase in equilibrium with graphite and native iron is CO-dominated, regardless the initial conditions (Fig. 1, Fig. SM1, and Table 2). Figure 5a presents the same results as Figure 1d, with the difference that the composition of the fluid phase is expressed in wt $\%$ of the magma. We calculated that graphite and native iron-saturated lavas like those observed at Disko and Bühl degassed $1.3 \mathrm{wt} \% \mathrm{CO}$, the other gas components representing less than $0.1 \mathrm{wt} \%$ (Table 2). These estimations take into account only the contribution of reactions (11) and (12), without considering the additional production of $\mathrm{CO}$ associated to native iron formation (reaction 13) and are hence minima. We also recall that an oxygen-free organic matter was considered in our calculations; the presence of oxygen in the assimilated organic matter would result in a higher degree of assimilation and therefore in a higher $\mathrm{CO}$ production. Fluid bubbles hosted in the groundmass glass of native iron-bearing Disko basalts were investigated by heating and cooling microscopic techniques, revealing strongly reduced volatile molecules most likely formed during the magmatic stage (Solovova et al., 2002). The estimated fluid composition at $\sim 1180^{\circ} \mathrm{C}$ and pressures lower than $10 \mathrm{MPa}$ is $\mathrm{CO}-\mathrm{H}_{2}$ dominated (Solovova et al., 2002).

As native iron was observed not only in basaltic flows, but also in subvolcanic intrusions that were probably emplaced a few hundred meters deep (e.g. in North Siberia, see previous section), we also calculated the composition of the fluid phase in equilibrium with graphite and native iron at $10 \mathrm{MPa}$ (i.e. the maximum depth for native iron crystallization calculated at $1200^{\circ} \mathrm{C}$ ). At $10 \mathrm{MPa}$, saturation in graphite and native iron is reached for $\sim 0.5 \mathrm{wt} \% \mathrm{CH}$ or $\mathrm{CH}_{2}$ addition. Figure $5 \mathrm{~b}$ and Table 2 show that, although the coexisting fluid phase is still largely CO-dominated, calculated CO contents of the magma are slightly lower $(\sim 1.0 \mathrm{wt} \%)$, and those of the other components slightly higher (but always $<0.1 \mathrm{wt} \%$ ) than at $0.1 \mathrm{MPa}$. 
Again, these estimations consider only reactions (11) and (12) and not (13). In the absence of robust constraints on the degree of metallisation of iron in the native iron-bearing basalts we cannot correctly estimate the amount of CO produced by reaction (13), which is nevertheless potentially significant. A maximum estimate can be done by considering that all $\mathrm{FeO}$ initially present in the basalt ( $8 \mathrm{wt} \%$ ) has been transformed into native iron: this would have produced additional $3.1 \mathrm{wt} \% \mathrm{CO}$, which then totalizes $\sim 4.2 \mathrm{wt} \%$ of the magma (Table 2). Even if this additional contribution is not considered, both Figure 5 and Table 2 clearly show how the ingestion of only $0.6 \mathrm{wt} \%$ of organic matter by a basalt strongly enhances magma degassing: the total volatile content of the magma increases from $\sim 0.9 \mathrm{wt} \%$ in the absence of assimilation to $\sim 1.5 \mathrm{wt} \%$ at $0.1 \mathrm{MPa}$ (Fig. 5a, Table 2), and from $\sim 0.5 \mathrm{wt} \%$ to $\sim 1.2 \mathrm{wt} \%$ at $10 \mathrm{MPa}$ (Fig. $5 b$, Table 2).

If the temperature of magmatic gases decreases during ascent after separation from the magma, their composition would change from $\mathrm{CO}$ toward $\mathrm{H}_{2} \mathrm{O}-\mathrm{CH}_{4}-\mathrm{CO}_{2}$-dominated (Fig.4b). For instance, at $300^{\circ} \mathrm{C}$ the calculated gas composition is $\sim 46 \mathrm{wt} \% \mathrm{H}_{2} \mathrm{O}, 28 \mathrm{wt} \% \mathrm{CH}_{4}$ and 26 $\mathrm{wt} \% \mathrm{CO}_{2}$.

The enhanced magmatic degassing of $\mathrm{C}$ species (including $\mathrm{CO}$ at high temperatures and $\mathrm{CH}_{4}$ $\mathrm{CO}_{2}$ at low temperature) is likely to have environmental implications when the associated magma production rate is high. The emplacement of Disko and Nuussuaq lavas that belong to the North Atlantic Large igneous Province (Storey et al., 1998) could have caused environmental damages, due to the large volumes of magma that were contaminated by organic matter-rich sediments (Pedersen and Larsen, 2006). Lethal hazard for animal life has been invoked at a local scale due to intense $\mathrm{CO}$ and $\mathrm{CO}_{2}$ emanations (Pedersen and Larsen, 2006). A global impact of these gas emissions can also be speculated: magmatic activity in Western Greenland precedes the Paleocene-Eocene hyperthermal (rapid and transient global 
warming events) and several authors have suggested that the two events can be related (e.g. Kennett and Stott, 1991; Wignall, 2001).

Siberian magmatism/volcanismis another case in point: it has often been proposed to have caused the end-Permian crisis, and the strong perturbation of the Earth's carbon cycle, globally marked by a negative carbon isotope excursion (e.g. Wignall, 2001). In particular, the interaction between magmas and carbonaceous sediments has been proposed as the major cause of the environmental impact of the Siberian Trap emplacement (e.g. Svensen et al., 2009). In a companion paper (Iacono-Marziano et al., submitted to EPSL) we quantify the gas production potential of a single intrusive event in coal-bearing sediments at the Siberian Traps and investigate the dispersion of these gases in the atmosphere. We also discuss the potential impact of these gas emissions on the environment, distinguishing short term implications at a local scale from long term ones at the global scale.

The process described and quantified here could concern not only LIP sized events, but also much smaller intrusions/eruptions. Virtually any active volcanic area whose sedimentary substrata comprise layers of organic-rich material can produce important amounts of CO, with potentially dangerous consequences for nearby human beings.

\section{Conclusions}

The long term volatile cycle is generally described as the exchange between two major reservoirs, the mantle and the atmosphere, where volcanism has the role of conveying volatiles from the mantle to the surface (e.g. Hilton et al., 2002; Wallace, 2005). Recent studies have however revealed that magma-host rock interaction may contribute additional gases, in particular when host rocks are composed of carbonates, evaporites or organic matter (Svensen et al., 2004, 2007, 2009; Iacono-Marziano et al., 2007, 2009; Ganino and Arndt, 2009). In this paper, we show that another crucial effect of magma-host rock interactions is 
that they can impact severely on the redox state of the magma and thus that of volcanic gases. Very minor amounts of organic matter $(<0.5 \mathrm{wt} \%)$ assimilated by the magma decrease its redox state by several log-units. The assimilation of only $0.6 \mathrm{wt} \%$ of organic matter almost doubles its total volatile content and produces unusual $\mathrm{CO}$-dominated gases. We therefore conclude that while the long-term deep volatile cycle controls the background level of volcanic degassing, occasional interaction between magma and sedimentary host rocks may yield peak values of abnormal gas compositions, representing a potentially major perturbation of the volatile cycles.

\section{References}

Aiuppa, A., Moretti, R., Federico, C., Giudice, G., Gurrieri, S., Liuzzo, M., Papale, P., Shinohara, H., Valenza, M., 2007. Forecasting Etna eruptions by real-time observation of volcanic gas composition. Geology 35, 115-118.

Aiuppa, A., Giudice, G., Liuzzo, M., Tamburello, G., Allard, P., Calabrese, S., Chaplygin, I., McGonigle, A.J.S., Taran, Y., 2012. First volatile inventory fro Gorely volcano, Kamchatka.

Arndt, N.T., Lesher, C.M., Czamanske, G.K., 2005. Mantle-derived magmas and magmatic $\mathrm{Ni}-\mathrm{Cu}-(\mathrm{PGE})$ deposits. Econ. Geol., 100th Anniversary volume, 5-24.

Canil, D., 2002. Vanadium in peridotites, mantle redox and tectonic environments: Archean to present. Earth Planet. Sci. Lett. 195, 75-90.

Carmichael, I.S.E., 1991. The redox states of basic and silicic magmas- a reflection of their source region. Contrib. Mineral. Petrol. 106, 129-141.

Dixon, J., Clague, D.A., Cousens, B., Monsalve, M.L., Uhl, J., 2008. Carbonatite and silicate melt metasomatism of the mantle surrounding the Hawaiian plume: Evidence from volatiles, trace elements, and radiogenic isotopes in rejuvenated-stage lavas from Niihau, Hawaii, Geochem. Geophys. Geosyst., 9, Q09005, doi:10.1029/2008GC002076.

Edmonds M., Gerlach, T.M., 2007. Vapor segregation and loss in basaltic melts. Geology, 35, 751-754.

French, B.M., 1966. Some geological implications of equilibrium between graphite and a C$\mathrm{H}-\mathrm{O}$ gas phase at high temperatures and pressures. Rev. Geophys. 4, 223-253. 
French, B.M., Eugster, H.P., 1965. Experimental control of oxygen fugacities by graphite-gas equilibriums. J. Geophys. Res. 70, 1529-1539.

Gaillard, F., Scaillet B., 2009. The sulphur content of volcanic gases on Mars. Earth Planet. Sci. Lett. 279, 34-43.

Gaillard, F., Scaillet B., Arndt, N.T., 2011. Atmospheric oxygenation caused by a change in volcanic degassing pressure. Nature, 478, 229-232.

Ganino, C., Arndt, N. T., 2009. Climate changes caused by degassing of sediments during the emplacement of large igneous province. Geology 37, 323-326.

Ganino, C. Arndt N.T., Zhou M.F. Gaillard F., Chauvel C. 2008. Interaction of magma with sedimentary wall rock and magnetite ore genesis in the Panzhihua mafic intrusion, SW China. Mineralium Deposita 43, 677-694.

Gerlach, T.M., 1993. Oxygen buffering of Kilauea volcanic gases and the oxygen fugacity of Kilauea basalt. Geochim. Cosmochim. Acta, 57, 795-814.

Giggenbach, W.F., 1987. redox processes governing the chemistry of fumarolic gas discharges from White Island, New Zeland. App. Geochem. 2, 143-161.

Giggenbach, W.F., 1997. Relative importance of thermodynamic and kinetic processes in governing the chemical and isotopic composition of carbon gases in high-heatflow sedimentary basins. Geochim. Cosmochim. Acta 61, 3763-3785.

Henning A., van der Westhuizen W.A., de Bruiyn H., Beukes G.J., 1997. Hydrothermal Cu$\mathrm{Ni}-\mathrm{Au}-\mathrm{Ag}$ mineralization in a granodiorite sill north of Cradock, Republic of South Africa. Mineral. Dep. 32, 410-418.

Hetenyi, M., 1998. Oxygen index as an indicator of early organic maturity. Org. Geochem. 29, 63-77.

Hilton D.R., Fischer T.P., Marty B., 2002. Noble gases and volatile recycling at subduction zones. Rev. Miner. 47, 319-370.

Holland, H.D., 2002. Volcanic gases, black smokers, and the Great Oxidation Event. Geochim. Cosmochim. Acta 66, 3811-3826.

Holloway, J.R., 1987. Igneous fluids. Reviews in Mineralogy and Geochemistry 17, 211-233.

Iacono-Marziano, G., Gaillard, F., Pichavant, M., 2007. Limestone assimilation and the origin of $\mathrm{CO}_{2}$ emissions from the Alban Hills (Central Italy): constraints from experimental petrology. J. Volcanol. Geotherm. Res. 166, 91-105.

Iacono-Marziano, G., Gaillard, F., Scaillet, B., Pichavant, M., Chiodini, G., 2009. Role of non-mantle $\mathrm{CO}_{2}$ in the dynamics of volcano degassing: The Mount Vesuvius example. Geology 37, 319-322. 
Iacono-Marziano G., Marecal V., Pirre M., Gaillard F., Scaillet B., Arndt N.T. Gas emissions due to magma-sediment interactions during flood magmatism at the Siberian Traps: gas dispersion and environmental consequences. Submitted to Earth Planet. Sci. Lett.

Iacono-Marziano G., Morizet Y., Le Trong E., Gaillard F, in press. New experimental data and semi-empirical parameterization of $\mathrm{H}_{2} \mathrm{O}-\mathrm{CO}_{2}$ solubility in mafic melts. Geochim. Cosmochim. Acta, doi 10.1016/j.gca.2012.08.035.

Jambon A., 1994. Earth degassing and large-scale geochemical cycling of volatile elements. In Volatiles in Magmas, M.R. Caroll and J.R. Holloway eds. Reviews in Mineraglogy and Geochemistry 30, 479-517.

Kennett, J.P., Stott, L.D., 1991. Abrupt deep-sea warming, palaeoceanographic changes and benthic extinctions at the end of the Palaeocene. Nature 353, 225-229.

Kress, V.C., Carmichael, I.S.E., 1991. The compressibility of silicate liquids containing $\mathrm{Fe} 2 \mathrm{O} 3$ and the effect of composition, temperature, oxygen fugacity and pressure on their redox states. Contrib. Mineral. Petrol. 108, 82-92.

Kump, L.R., Barley, M.E., 2007. Increased subaerial volcanism and the rise of atmospheric oxygen 2.5 billion years ago. Nature 448,1033-1036.

Li, Z.X.A., Lee, C.T.A., 2005. The constancy of upper mantle $\mathrm{fO}(2)$ through time inferred from V/Sc ratios in basalt. Earth Planet. Sci. Lett. 228, 483-493.

Mavrogenes, J.A., O'Neill, H.S.C., 1999. The relative effect of pressure, temperature and oxygen fugacity on the solubility of sulphide in mafic magmas. Geochim. Cosmochim. Acta 63, 1173-1180.

Medenbach, O., ElGoresy A., 1982. Ulvöspinel in native iron-bearing assemblages and the origin of these assemblages in basalts from Ovifak, Greenland, and Bühl, Federal Republic of Germany. Contrib. Mineral. Petrol. 80, 358-366.

Melson, W.G., Switzer, G., 1966. Plagioklase-Spinel-Graphite Xenoliths in Metallic IronBearing Basalts, Disko-Island, Greenland. Am. Mineral. 51, 664-676.

Metrich, N., Allard, P., Aiuppa, A., Bani, P., Bertagnini, A., Shinohara, H., Parello, F., Di Muro, A., Garaebiti, E., Belhadj, O., Massare D., 2011. Magma and volatile supply to post-collapse volcanism and block resurgence in Siwi Caldera (Tanna Island, Vanuatu Arc). J. Petrol. 52, 1077-1105.

Moretti, R., Papale, P., 2004. On the oxidation state and volatile behavior in multicomponent gas-melt equilibria, Chem. Geol. 213, 265-280.

Morizet, Y., Paris, M., Gaillard, F., Scaillet, B. 2010. C-O-H fluid solubility in haplobasalt under reducing conditions: An experimental study. Chem. Geol. 279, 1-16. 
Nordenskjöld, A.E., 1872. Account of an expedition to Greenland in the year 1870, Part I-V. Geol. Mag. 1872.

Ortega, L., Millward, D., Luque, F.J., Barrenechea, J.F., Beyssac, O., Huizenga, J.M., Rodas, M., Clarke, S.M., 2010. The graphite deposit at Borrowdale (UK): A catastrophic mineralizing event associated with Ordovician magmatism. Geochim. Cosmochim. Acta $74,2429-2449$.

Pan, V., Holloway, J.R., Hervig, R.L., 1991. The pressure and temperature-dependence of carbon dioxide solubility in tholeiitic basalt melts. Geochim. Cosmochim. Acta 55, 15871595.

Pedersen, A.K., 1978. Non-stoichiometric magnesian spinels in shale xenoliths from a native iron-bearing andesite at Asuk, Disko, Central West Greenland. Contrib. Mineral. Petrol. 67, 331-340.

Pedersen, A.K., 1979a. A shale buchite xenolith with Al-Armalcolite and native iron in a lava from Asuk, Disko, Central West Greenland. Contrib. Mineral. Petrol. 69, 83-94.

Pedersen, A.K., 1979b. Basaltic glass with high-temperature equilibrated immiscible sulphide bodies with native iron from Disko, central West Greenland. Contrib. Mineral. Petrol. 69, $397-407$.

Pedersen, A.K., 1985. Reaction between picrite magma and continental crust: early Tertiaty silicic basalts and magnesian andisites from Disko, West Greenland. Bull. Groenl. Geol. Unders., 152, 126pp.

Pedersen, A.K., Larsen, L.M., 2006. The Ilugissoq graphite andesite volcano, Nuussuaq, central West Greenland. Lithos 92, 1-19.

Retallack, G., Jahren, A.H., 2008. Methane release from igneous intrusion of coal during Late Permian extinction events. J. Geol. 116, 1-20.

Ryabov, V. V., Lapkovsky A. A., 2010. Native iron (-platinum) ores from the Siberian Platform trap intrusions. Austral. J. Earth Sci. 57, 707-736.

Ryabov, V.V., Ponomarchuk, V.A., Talibova, A.G., 2006. Bitumen, graphite and carbonaceous matter in the rocks and ores of northwestern Siberian Platform: occurrence and isotope composition of carbon. In: Topical problems of ore formation and metallogeny: theses of the International meeting devoted to the 100th anniversary of academician V. A. Kuznetsov, pp. 189-190. GEO Publisher, Novosibirsk (in Russian).

Saunders A.D., England R.W., Reichow M.K., White R.V., 2005. A mantle plume origin for the Siberian traps: uplift and extension in the West Siberian Basin, Russia. Lithos 79, 407424. 
Shi, P.F., Saxena, S.K., 1992. Thermodynamic modelling of the C-H-O-S fluid system. Americ. Mineral. 77, 1038-1049.

Solovova, I.P., Ryabchikov, I.D., Girnis, A.V., Pedersen, A., Hansteen, T., 2002. Reduced magmatic fluids in basalt from the island of Diskp, central West Greenland. Chem. Geol. $183,365-371$.

Steenstrup, K.J.V., 1884. On the Existence of Nickel-iron with Widmannstatten's Figures in the Basalt of North Greenland. Mineral. Mag. VI, 27,1-13.

Storey, M., Duncan, R.A., Pedersen, A.K., Larsen L.M., Larsen H.C., 1998. 40Ar/39Ar geochronology of the West Greenland Tertiary volcanic province. Earth Planet. Sci. Lett. $160,569-586$.

Svensen, H. Planke, S., Malthe-Sørenssen, A., Jamtveit , B., Myklebust, R., Eidem, T., Rey, S.S., 2004. Release of methane from a volcanic basin as a mechanism for initial Eocene global warming. Nature 429, 542-545.

Svensen H., Planke, S., Chevallier, L., Malthe-Sørenssen , A., Corfu, B., and Jamtveit, B., 2007. Hydrothermal venting of greenhouse gases triggering Early Jurassic global warming. Earth Planet. Sci. Lett. 256, 554-566.

Svensen, H., Planke S., Polozov A.G., Schmidbauer N., Corfu F., Podladchikov Y.Y., Jamtveit B. 2009. Siberian gas venting and the end-Permian environmental crisis. Earth Planet. Sci. Lett. 277, 490-500.

Symonds, R.B, Reed, M.H., 1993. Calculation of multicomponent chemical equilibria in gassolid-liquid systems: Calculation methods, thermochemical data and applications to studies of high-temperature volcanic gases with examples from Mount St. Helens: Am. J. Sci. 293, 758-864.

Symonds, R.B., Rose, W.I., Bluth, G., and Gerlach, T.M., 1994. Volcanic gas studies: methods, results, and applications. In Carroll, M.R., Holloway, J.R., eds. Volatiles in Magmas. Mineral. Soc. Am. Rev. Mineral. 30, 1-66.

Trail, D., Watson, E.B., Tailby, N.D., 2011. The oxidation state of Hadean magmas and implications for early Earth's atmosphere. Nature 480, 79-82.

Troll, V.R., Hilton, D.R., Jolis, E.M., Chadwick, J.P., Blythe, L.S., Deegan, F.M., Schwarzkopf, L.M., Zimmer, M., 2012. Crustal CO2 liberation during the 2006 eruption and earthquake events at Merapi volcano, Indonesia. Geophys. Res. Lett. 39, DOI: 10.1029/2012GL051307. 
Ulff-Møller, F., 1985. Solidification history of the Kitdlidt lens: immiscible metal and sulphide liquids from a basaltic dyke on Disko, central West Greenland. J. Petrol. 26, 6491.

Wallace, P.J., 2005. Volatiles in subduction zone magmas: concentrations and fluxes based on melt inclusion and volcanic gas data. J. Volcanol. Geotherm. Res. 140, 217-240.

Wignall, P. B., 2001. Large igneous provinces and mass extinctions. Earth Sci. Rev. 53, 1-33.

\section{Acknowledgements}

G.I.M. was founded by the European Community's Seventh Framework Programme (grant agreement $n^{\circ}$ PIEF-GA-2008-220926). F.G. was supported by the ERC grant number 279097. This work benefited from conversations with Jean-Robert Disnar and Jérémy Jacob. We thank B. Marty for the careful handling of the manuscript, H. Svensen and an anonymous reviewer for their constructive comments that greatly improved the paper. 
Table 1. Numerically tested configurations of organic matter assimilations by basalts.

\begin{tabular}{|c|c|c|c|c|c|c|}
\hline $\mathbf{N}^{\circ}$ & $\begin{array}{c}\text { Redox } \\
\text { conditions }{ }^{\text {a }}\end{array}$ & $\begin{array}{c}\text { Gas } \\
\text { content }\end{array}$ & $\begin{array}{r}\text { Volatile contents } \\
\mathrm{H}_{2} \mathrm{O}(\mathrm{wt} \%)\end{array}$ & $S(w t \%)$ & $\mathrm{CO}_{2}(\mathrm{wt} \%)$ & $\begin{array}{l}\text { Organic } \\
\text { matter }^{d}\end{array}$ \\
\hline$\# 1$ & FMQ & $0.3 \%$ & 0.5 & 0.1 & 0.24 & $\mathbf{C H}$ \\
\hline$\# 2$ & FMQ & $0.3 \%$ & 0.2 & 0.1 & 0.24 & CH \\
\hline \#3 & FMQ & $0.3 \%$ & 1.0 & 0.1 & 0.24 & $\mathbf{C H}$ \\
\hline \#4 & FMQ & $2.1 \%$ & 0.5 & 0.1 & 2.00 & CH \\
\hline$\# 5$ & FMQ & $0.7 \%$ & 0.5 & 0.1 & 0.64 & $\mathbf{C H}$ \\
\hline \#6 & NNO & $0.3 \%$ & 0.5 & 0.1 & 0.24 & CH \\
\hline$\# 7$ & NNO & $0.7 \%$ & 0.5 & 0.1 & 0.64 & $\mathbf{C H}$ \\
\hline \#8 & NNO & $0.7 \%$ & 0.2 & 0.1 & 0.64 & $\mathbf{C H}$ \\
\hline \#9 & NNO & $0.7 \%$ & 1.0 & 0.1 & 0.64 & CH \\
\hline \#10 & FMQ & $0.3 \%$ & 0.5 & 0.1 & 0.24 & $\mathrm{CH}_{2}$ \\
\hline \#11 & FMQ & $0.7 \%$ & 0.5 & 0.1 & 0.64 & $\mathrm{CH}_{2}$ \\
\hline \#12 & NNO & $0.3 \%$ & 0.5 & 0.1 & 0.24 & $\mathrm{CH}_{2}$ \\
\hline$\# 13$ & NNO & $0.7 \%$ & 0.5 & 0.1 & 0.64 & $\mathrm{CH}_{2}$ \\
\hline
\end{tabular}

All calculations have been conducted at $1200^{\circ} \mathrm{C}$, with pressure varying from 200 to 0.1 MPa.

${ }^{\text {a }}$ Initial redox conditions of the basaltic magma at $200 \mathrm{MPa}$ and $1200^{\circ} \mathrm{C}$

${ }^{\mathrm{b}}$ Initial gas content of the basaltic magma at $200 \mathrm{MPa}$ and $1200^{\circ} \mathrm{C}$

c Initial volatile contents (dissolved in the melt + in the form of bubbles) of the basaltic magma at $200 \mathrm{MPa}$ and $1200^{\circ} \mathrm{C}$

d Type of organic matter assimilated

Table 2. Fluid phase composition in equilibrium with graphite and native iron.

\begin{tabular}{|c|c|c|c|c|}
\hline $\begin{array}{l}\text { Emitted } \\
\text { species }\end{array}$ & $\begin{array}{l}10 \mathrm{MPa} \\
(\mathrm{wt} \%)^{\mathrm{a}}\end{array}$ & $\begin{array}{r}0.1 \mathrm{MPa} \\
(\mathrm{wt} \%)^{\mathrm{a}}\end{array}$ & $\begin{array}{r}10 \mathrm{MPa} \\
\text { without assimil. } \\
(w \mathrm{t} \%)^{\mathrm{b}}\end{array}$ & $\begin{array}{r}\text { 0.1 MPa } \\
\text { without assimil. } \\
(\mathrm{wt} \%)^{\mathrm{b}}\end{array}$ \\
\hline $\mathrm{CO}$ & $1.00-1.09$ & $1.46-1.50$ & 0.02 & 0.03 \\
\hline $\mathrm{CO}^{*}$ & 3.11 & 2.22 & & \\
\hline $\mathrm{CO}_{2}$ & 0.08 & 0.00 & 0.35 & 0.31 \\
\hline $\mathbf{H}_{2}$ & 0.04 & 0.04-0.07 & 0.00 & 0.00 \\
\hline $\mathrm{H}_{2} \mathrm{O}$ & 0.03-0.04 & 0.00 & 0.07 & 0.40 \\
\hline $\mathbf{H}_{2} \mathrm{~S}$ & 0.02-0.03 & 0.00 & 0.02 & 0.03 \\
\hline $\mathrm{CH}_{4}$ & 0.02 & 0.00 & 0.00 & 0.00 \\
\hline $\mathbf{S}_{\mathbf{2}}$ & 0.00 & 0.00 & 0.02 & 0.04 \\
\hline $\mathrm{SO}_{2}$ & 0.00 & 0.00 & 0.03 & 0.14 \\
\hline Tot & $1.19-4.41$ & $1.50-3.79$ & 0.51 & 0.95 \\
\hline
\end{tabular}

a) Gas abundances (in wt\% of the magma) produced by high temperature assimilation of organic matter. Given ranges account for the variations in initial conditions (initial $\mathrm{fO}_{2}$ and gas fraction of the magma), type of organic matter assimilated, i.e. $\mathrm{CH}$ or $\mathbf{C H}_{2}$ and amount of organic matter necessary to reach graphite-native iron saturation (see Section 3.1 for explanation).

b) Gas species produced by the degassing of a basaltic magma (initial $\mathrm{H}_{2} \mathrm{O}, \mathrm{CO}_{2}$ and $\mathrm{S}$ contents of $0.50,0.08$ and $0.10 \mathrm{wt} \%$, respectively) without assimilation.

* carbon monoxide produced by reaction 13 in the text. 


\section{Figure Captions}

\section{Fig.1}

Gas compositions at $0.1 \mathrm{MPa}$ expressed in mole fraction as a function of the amount of organic matter assimilated. The effects of different initial conditions of oxygen fugacity (NNO or FMQ), gas proportion in the magma ( 0.3 or $0.7 \%$ ) and type of organic matter assimilated $\left(\mathrm{CH}\right.$ or $\left.\mathrm{CH}_{2}\right)$ are shown. Four different configurations listed in Table 1 are shown: \#7 (a), \#1 (b), \#13 (c), \#10 (d). Black and red lines indicate the amount of organic matter necessary to reach graphite and native iron saturation, respectively.

\section{Fig.2}

Graphite and iron saturation as a function of pressure (and roughly of depth) for $\mathrm{CH}$ and $\mathrm{CH}_{2}$ addition. Calculations for $\mathrm{CH}$ assimilation were performed using initial $\mathrm{fO}_{2}$ of FMQ and NNO and initial gas fraction of 0.3 and $0.7 \%$. Only the two extreme cases $\left(\mathrm{fO}_{2}=\mathrm{FMQ}\right.$, gas fraction $=0.3 \%$ and $\mathrm{fO}_{2}=\mathrm{NNO}$, gas fraction $=0.7 \%$ ) are shown for $\mathrm{CH}_{2}$. Variations between the different cases are always within $30 \%$. The presence of graphite alone in a magmatic rock does not clearly indicate the amount of organic matter assimilated by the basaltic magma, because of the strong dependence on the depth of the intrusion emplacement. On the contrary, the coexistence of graphite and native iron precisely constraints the minimum amount of $\mathrm{CH}$ or $\mathrm{CH}_{2}(0.5-0.8 \mathrm{wt} \%)$ assimilated at depths lower than 350-500 $\mathrm{m}$ (depending on the density of the sedimentary host rocks).

\section{Fig. 3}

Variation of the oxygen fugacity of the magma (expressed as logarithmic units relative to the FMQ buffer) as a function of the amount of coal assimilated. Calculations were performed at $1200^{\circ} \mathrm{C}$ and $10 \mathrm{MPa}$ using pre-assimilation $\mathrm{fO}_{2}$ of FMQ and volatile contents of $0.50 \mathrm{wt} \%$ of $\mathrm{H}_{2} \mathrm{O}, 0.10$ wt $\%$ of $\mathrm{S}$ and $0.24 \mathrm{wt} \% \mathrm{CO}_{2}$ (corresponding to a gas fraction of $0.3 \%$ at 200 $\mathrm{MPa})$. Red and black lines indicate native iron and graphite saturation, respectively.

\section{Fig. 4}

Calculated gas compositions as a function of temperature for $\sim 0.6 \mathrm{wt} \% \mathrm{CH}$ assimilated (required for both graphite and iron saturation). Two different final pressures are shown: 0.1 $\mathrm{MPa}(\mathrm{a})$ and $10 \mathrm{MPa}(\mathrm{b})$. 


\section{Fig. 5}

Gas contents of the magma (expressed in wt\%) at $0.1 \mathrm{MPa}$ (a) and $10 \mathrm{MPa}$ (b) as a function of the amount of organic matter assimilated. Calculations were performed using initial $\mathrm{fO}_{2}$ of FMQ and initial gas fraction of $0.3 \%$. The lines indicate the amount of organic matter necessary to reach graphite and iron saturation and the composition of the coexisting gas phase. 

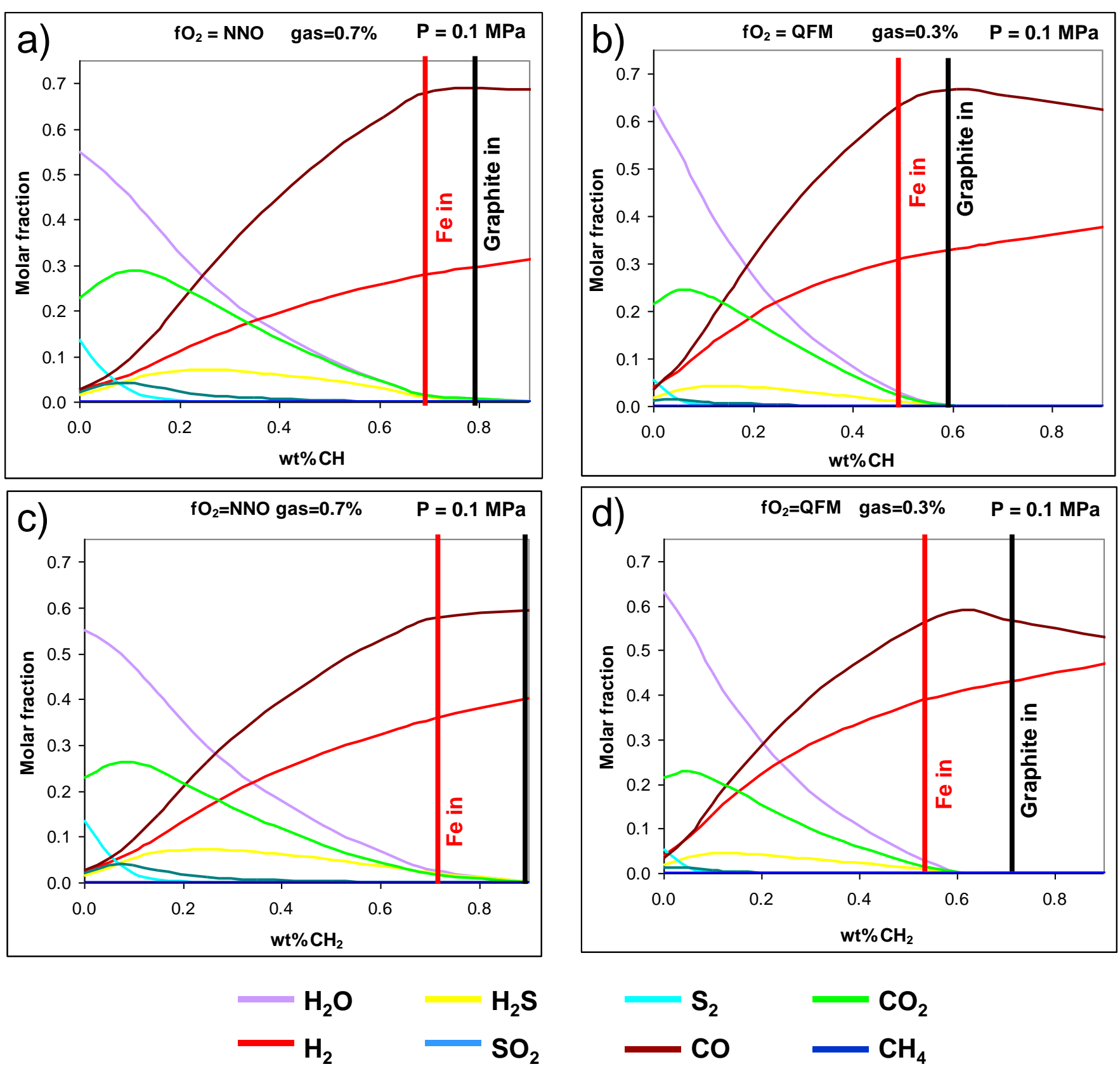

Fig. 1 


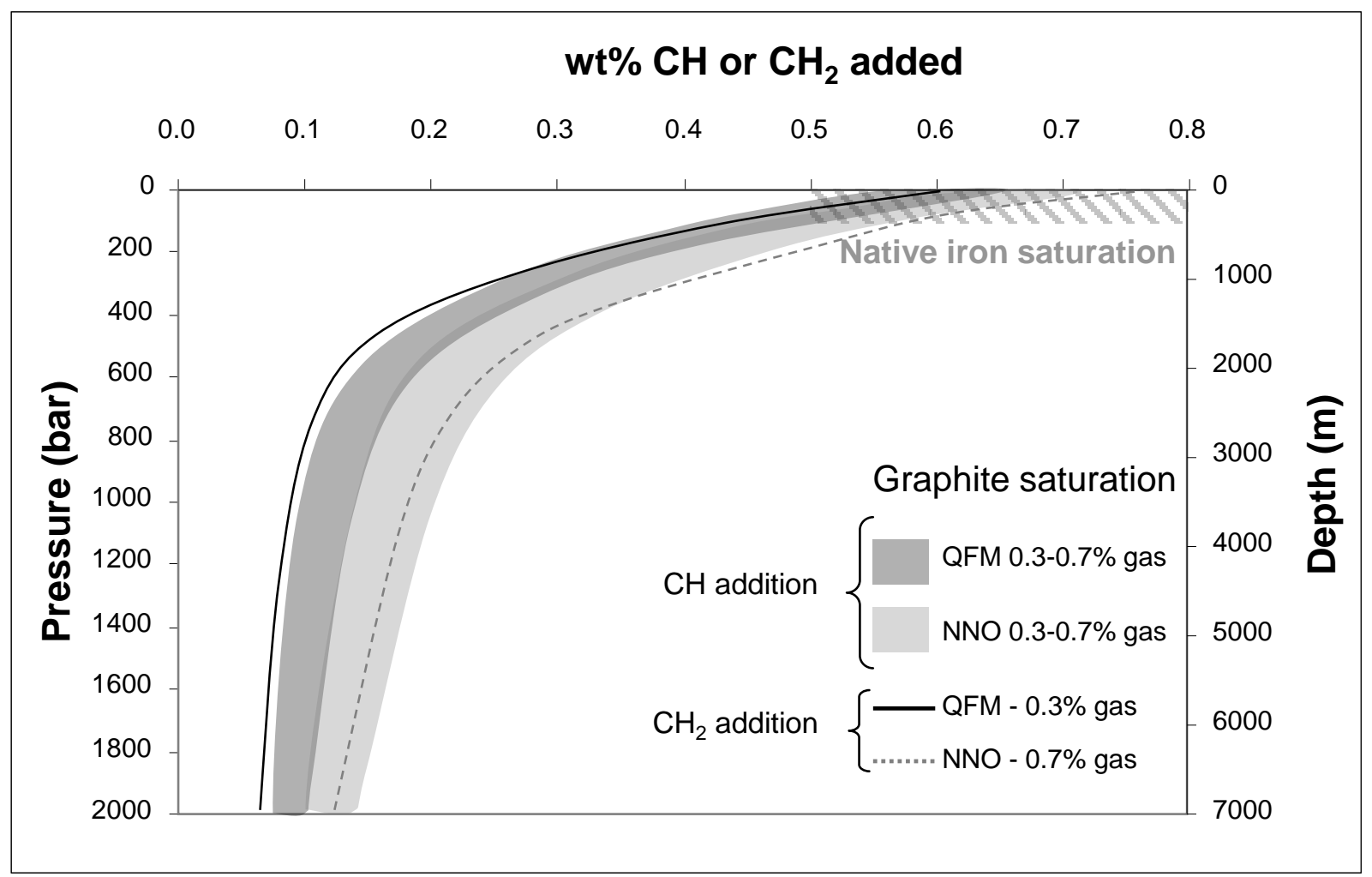

Fig.2 


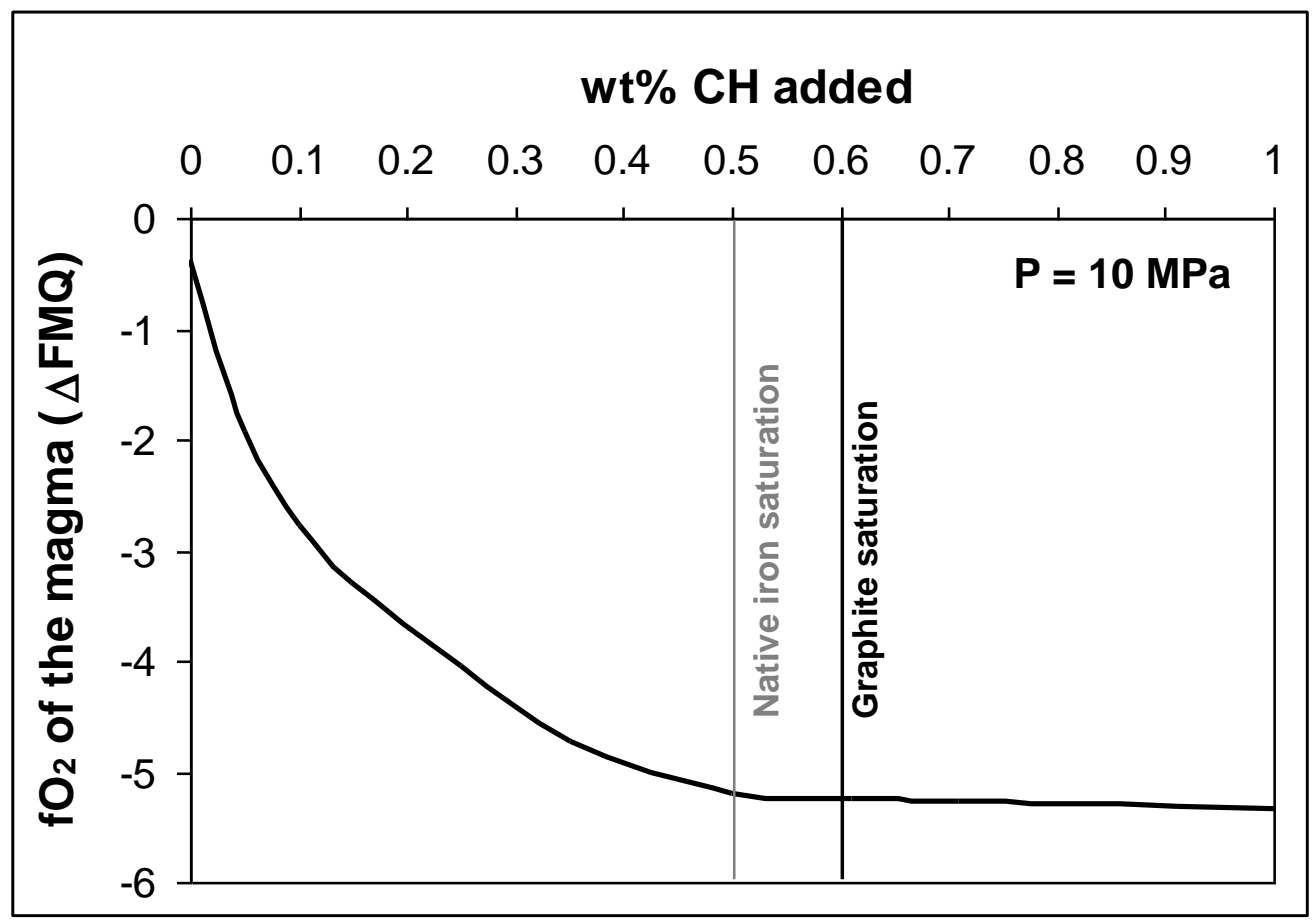

Fig. 3 

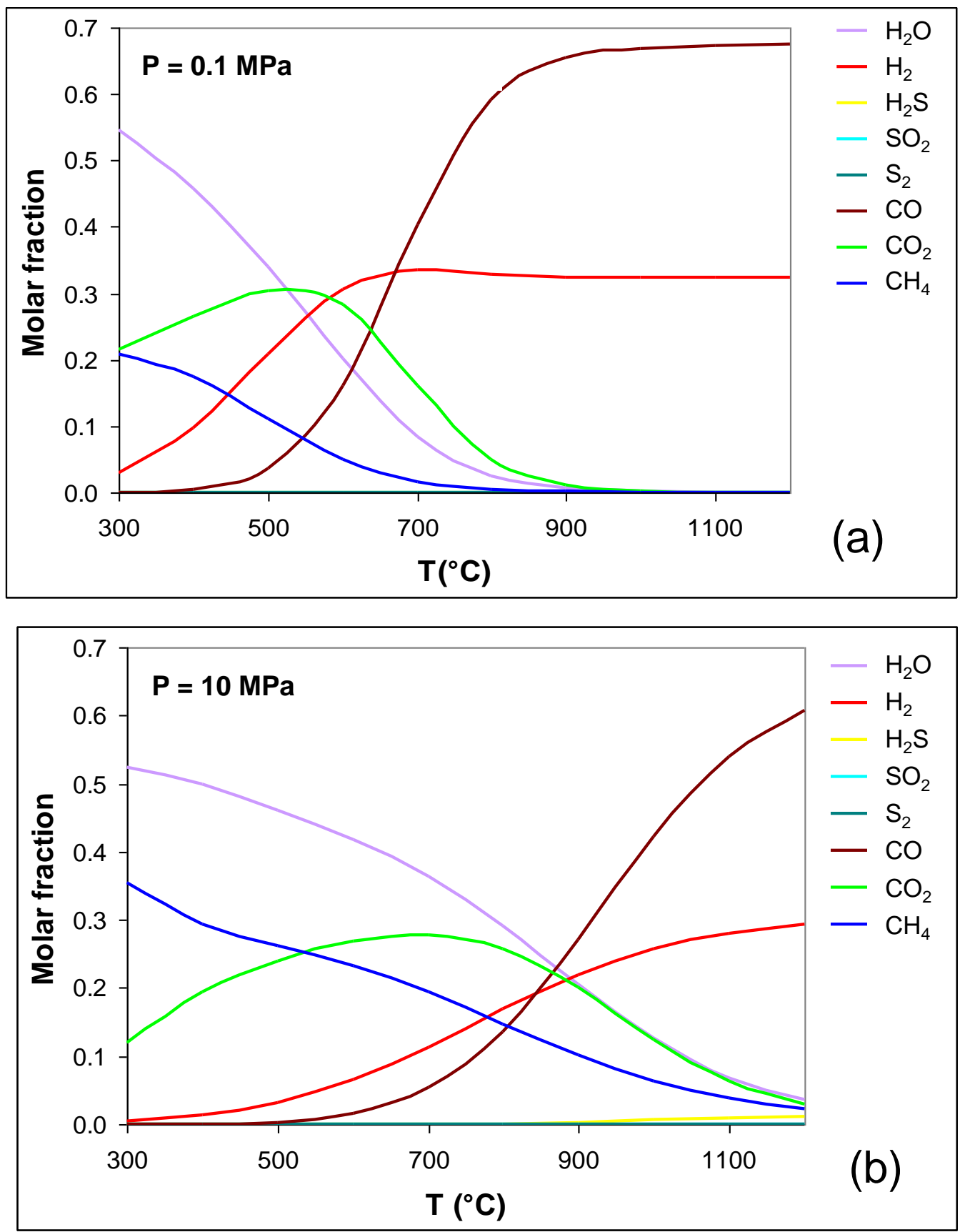

Fig. 4 


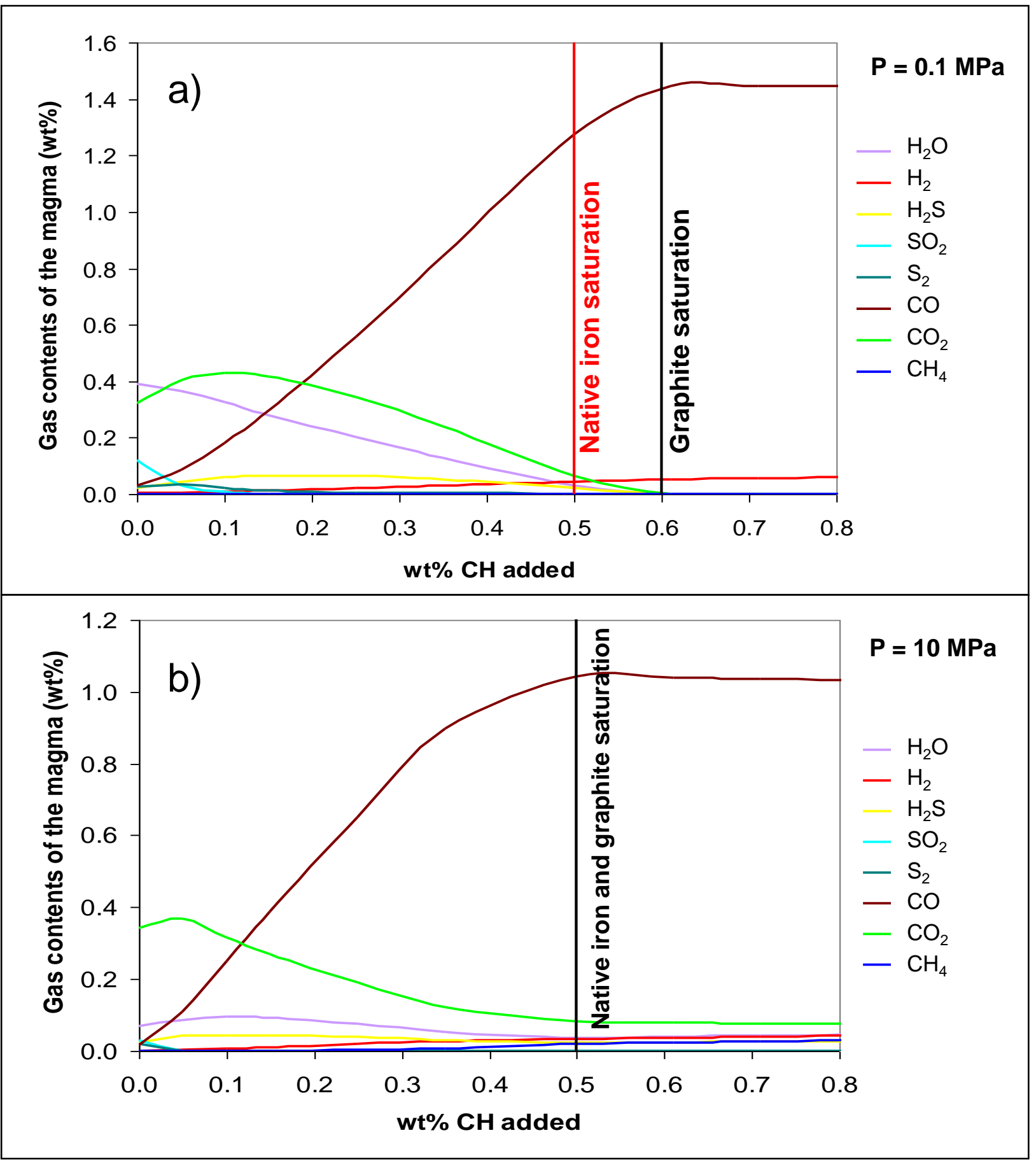

Fig.5 